\title{
Unravelling the effects of crustal assimilation versus mantle source heterogeneity in Tuli basin picrites, Karoo LIP
}

GEOFFREY H. HOWARTH ${ }^{1}$, JULIAN S. MARSH ${ }^{2}$, ANDY R. DUNCAN ${ }^{1}$, CHRIS HARRIS ${ }^{1}$, PETRUS LE ROUX ${ }^{1}$, JUSSI $S_{S}$ HEINONEN ${ }^{3}$ AND DR. OSVALDO GONZÁLEZ-MAUREL, PHD $^{1}$

${ }^{1}$ University of Cape Town

${ }^{2}$ Rhodes University

${ }^{3}$ University of Helsinki

Presenting Author: geoffrey.howarth@uct.ac.za

Crustal assimilation is a common processes affecting basaltic magmas that traverse thick crustal sequences. Discriminating crustal assimilation from mantle sources, however, is not straightforward. We present $\mathrm{Sr}-\mathrm{Nd}$ isotope and incompatible trace element (ITE) data from a $538 \mathrm{~m}$ deep borehole intersecting the transition from picrite to basalt at the base of the Tuli basin high-Ti lavas, Karoo CFB, in order to assess crustal assimilation relative to mantle source heterogeneity. From $538 \mathrm{~m}$ to $300 \mathrm{~m}$, picrites display gradual decrease in ITE concentrations (e.g., Ba 864 to $476 \mathrm{ppm})$, decrease in $\mathrm{Zr} / \mathrm{Y}$ (16.7 to 10.7), decrease in $\mathrm{Th} / \mathrm{Nb}(0.17$ to 0.14$)$, decrease in $\left({ }^{87} \mathrm{Sr} /{ }^{86} \mathrm{Sr}\right)_{\mathrm{i}}(0.7055$ to 0.7050$)$, increase in $\varepsilon \mathrm{Nd}_{\mathrm{i}}(-8.5$ to -5.3$)$. At $\pm 300 \mathrm{~m}$, picrites transition to basalts and a large change in the chemistry is observed with a rapid increase in $\left({ }^{87} \mathrm{Sr} /{ }^{86} \mathrm{Sr}\right)_{\mathrm{i}}$ (up to 0.7060$)$, increase in $\mathrm{Th} / \mathrm{Nb}$ (up to 0.23 ), and decrease in $\varepsilon \mathrm{Nd}_{\mathrm{i}}$ (down to -8.9); at constant $\mathrm{Zr} / \mathrm{Y}$ ratio of \pm 9.5 . The range in $\mathrm{Zr} / \mathrm{Y}$ is interpreted to reflect a gradual increase in the degree of partial melting in the source, in the presence of residual garnet, over time. The low and constant $\mathrm{Zr} / \mathrm{Y}$ above $\pm 300 \mathrm{~m}$ reflects the highest degree of partial melting obtained in the source. At this point, crustal chambers developed and picrite parent melt evolved to basalt. The ITE enriched picrites and the range in $\left({ }^{87} \mathrm{Sr} /{ }^{86} \mathrm{Sr}\right)_{\mathrm{i}}$ and $\varepsilon \mathrm{Nd}_{\mathrm{i}}$ between $538 \mathrm{~m}$ and $300 \mathrm{~m}$ is interpreted to reflect a heterogeneous mantle source and cannot be reproduced by assimilation-fractional-crystallisation (AFC) modelling. In contrast, the major change in chemistry at $\pm 300 \mathrm{~m}$ likely reflects crustal assimilation during the initial formation of crustal staging chambers and the evolution to basaltic magmas. We show that picrites are derived directly from a heterogeneous mantle source can have similar initial $\mathrm{Sr}-\mathrm{Nd}$ isotopes to those affected by crustal assimilation. The major difference is in the degree of ITE enrichment. Highly ITE enriched low-degree partial melts do not show the effects of crustal assimilation, however, later stage, higher degree, partial melts that have lower ITE content may have undergone a stage of crustal assimilation during the development of crustal staging chambers and the evolution to basaltic magmas. 